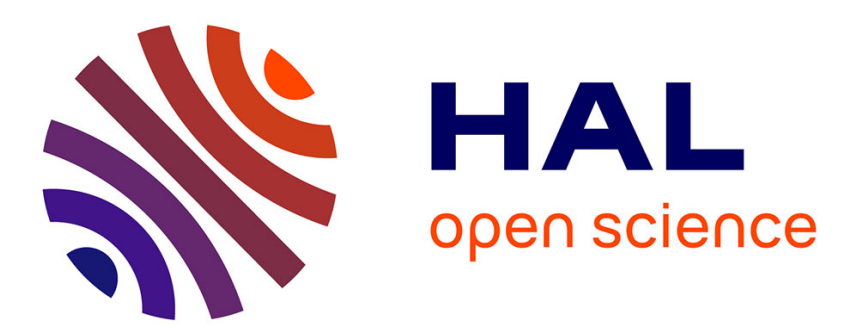

\title{
Late Ordovician scolecodonts from the Qusaiba-1 core hole, central Saudi Arabia, and their paleogeographical affinities
}

Olle Hints, Florentin Paris, Sa'Id Al-Hajri

\section{- To cite this version:}

Olle Hints, Florentin Paris, Sa'Id Al-Hajri. Late Ordovician scolecodonts from the Qusaiba-1 core hole, central Saudi Arabia, and their paleogeographical affinities. Review of Palaeobotany and Palynology, 2015, 212, pp.85-96. 10.1016/j.revpalbo.2014.08.013 . insu-01094285

HAL Id: insu-01094285

https://hal-insu.archives-ouvertes.fr/insu-01094285

Submitted on 12 Dec 2014

HAL is a multi-disciplinary open access archive for the deposit and dissemination of scientific research documents, whether they are published or not. The documents may come from teaching and research institutions in France or abroad, or from public or private research centers.
L'archive ouverte pluridisciplinaire HAL, est destinée au dépôt et à la diffusion de documents scientifiques de niveau recherche, publiés ou non, émanant des établissements d'enseignement et de recherche français ou étrangers, des laboratoires publics ou privés. 


\section{Accepted Manuscript}

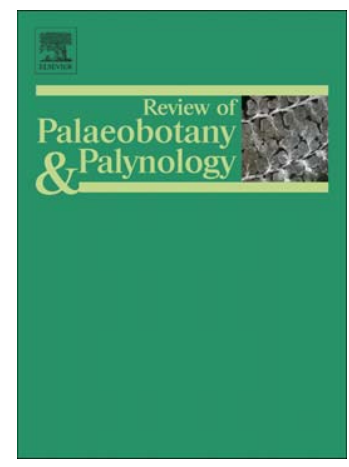

Late Ordovician scoleocodonts from the Qusaiba-1 core hole, central Saudi Arabia, and their paleogeographical affinities

Olle Hints, Florentin Paris, Sa'id Al-Hajri

PII: $\quad$ S0034-6667(14)00124-9

DOI: $\quad$ doi: $10.1016 /$ j.revpalbo.2014.08.013

Reference: $\quad$ PALBO 3560

To appear in: $\quad$ Review of Palaeobotany and Palynology

Received date: 29 March 2014

Accepted date: 21 August 2014

Please cite this article as: Hints, Olle, Paris, Florentin, Al-Hajri, Sa'id, Late Ordovician scoleocodonts from the Qusaiba-1 core hole, central Saudi Arabia, and their paleogeographical affinities, Review of Palaeobotany and Palynology (2014), doi: 10.1016/j.revpalbo.2014.08.013

This is a PDF file of an unedited manuscript that has been accepted for publication. As a service to our customers we are providing this early version of the manuscript. The manuscript will undergo copyediting, typesetting, and review of the resulting proof before it is published in its final form. Please note that during the production process errors may be discovered which could affect the content, and all legal disclaimers that apply to the journal pertain. 


\title{
Late Ordovician scoleocodonts from the Qusaiba-1 core hole, central Saudi Arabia, and their paleogeographical affinities
}

Olle Hints ${ }^{\text {a }}$, Florentin Paris ${ }^{\text {b,c }}$, Sa'id Al-Hajri ${ }^{\text {d }}$

\footnotetext{
${ }^{a}$ Institute of Geology at Tallinn University of Technology, Ehitajate 5, 19086 Tallinn, Estonia

${ }^{\mathrm{b}}$ Rue des Jonquilles, 35235 Thorigné-Fouillard, France

${ }^{\mathrm{c}}$ Géosciences-Rennes, CNRS UMR 6118, Université de Rennes 1, 35042 Rennes, France

${ }^{\mathrm{d}}$ Saudi Aramco, Exploration Technical Services Department, 31311 Dhahran, Saudi Arabia

* Corresponding author. Tel.: +372 51301 57; fax: +37263120 74. E-mail address: olle.hints@ttu.ee.
}

\begin{abstract}
This paper reports the discovery of Late Ordovician scolecodonts from the Qusaiba-1 core hole, central Saudi Arabia. The collection of about 100 relatively well preserved diagnostic jaws represents one of the richest jawed polychaete faunas from the Gondwanan realm and the first record of scolecodonts from the Arabian Peninsula. Scolecodonts were most diverse and abundant in the Quwarah Member and basal Sarah Formation, corresponding to the Ancyrochitina merga and Tanuchitina elongata chitinozoan zones (latest Katian to early Hirnantian). The polychaete assemblage contains up to 15 apparatus-based species and is dominated by the globally distributed genera Kettnerites, Oenonites and Atraktoprion, and a new genus of probable ramphoprionid affinity. Additionally, Skalenoprion and Kalloprion? are recorded, both for the first time from Gondwana. Characteristic of the assemblage is very
\end{abstract}


low frequency of taxa with placognath-type jaws. Comparing the Qusaiba-1 assemblage with coeval faunas of Baltica and Laurentia revealed that northern Gondwana was more similar to mid-continent Laurentia than Baltica. High proportion of paulinitids, ramphoprionids and atraktoprionids, and scarcity of placognaths is typical of both northern Gondwana and Laurentia. The Baltic faunas, in contrast, had several endemic genera particularly among placognaths, whereas paulinitids and ramphoprionids were rare. This anomalous biogeographic pattern, diverging from that of most other fossil groups, cannot be fully explained without additional first-hand data from the Middle and early Late Ordovician of Gondwana and Laurentia.

Key words: scolecodonts, polychaete jaws, Late Ordovician, Saudi Arabia, Gondwana, paleobiogeography

\section{Introduction}

Scolecodonts are the jaws of polychaete annelids, a group of soft-bodied worms that appeared in the Cambrian and flourish in present-day oceans. Unlike the body fossils of polychaetes, which are extremely rare, the organic-walled scolecodonts are common and diverse in Paleozoic marine sediments. They are frequently recovered from palynological samples together with chitinozoans and acritarchs. Although scolecodonts are known since 1850s, it was only in 1960s when the apparatus-based classification and acid extraction technique were widely adopted (Kielan-Jaworowska, 1966) and scolecodonts turned useful proxies for studying ecology, distribution and diversification of extinct polychaetes. Since then the 
collections and number of publications on scolecodonts have considerably increased (Hints and Eriksson, 2007a).

The main diversification episode of jaw-bearing polychaetes occurred during the Ordovician Period, when most families and genera characteristic of the Paleozoic first appeared. In spite of the fact that Ordovician scolecodonts are better known than those of any other time period, they have been thoroughly studied only in the Baltic area and partly in Laurentia, whereas data from the other regions and continents are very limited (for overview see Hints et al., 2004; Hints and Eriksson 2007a). In particular, the Ordovician polychaete faunas of the entire Gondwanan realm have remained poorly known. This, indeed, has limited our understanding of paleobiogeographical patterns as well as stratigraphical distribution and diversification of fossil jaw-bearing polychaetes. Hints and Eriksson (2007b) therefore concluded that more first-hand data from Gondwana are essential for improving the global biogeographic assessment.

Recent study of chitinozoans from the Qusaiba-1 shallow core, central Saudi Arabia (see Paris et al., this volume, a) revealed the occurrence of well-preserved scolecodonts in a number of Late Ordovician samples. Investigation of this material commenced in the frame of the French-Estonian collaboration project in 2007-2008, when the chitinozoan slides were examined and additional scolecodonts were picked from the palynological residues in the Rennes University, France. Although the obtained collection is small, especially when compared to data available from Baltica and Laurentia, it constitutes the richest scolecodont assemblage so far from the Ordovician of Gondwana, being also the first report of scolecodonts from the Arabian Peninsula. Preliminary results of this study were presented at 
the CIMP sponsored session at the 12th International Palynological Congress in Bonn (Hints et al., 2008). The aim of this paper is to describe this material in closer detail and discuss its paleobiogeographical significance.

\section{Locality and stratigraphy}

The Arabian Peninsula constituted the western part of the Gondwana supercontinent during the Ordovician and Silurian (Cocks and Torsvik, 2004). The Qusaiba-1 shallow core hole was drilled near the deserted Qusaiba village, ca. $75 \mathrm{~km} \mathrm{NNW}$ of Buraydah, Al-Qassim Province, central Saudi Arabia (Fig. 1), with the aim of obtaining unweathered samples for palynology and a continuous stratigraphic record of Late Ordovician and early Silurian strata. Full details of the sedimentology and stratigraphy of the Qusaiba-1 section are provided by Melvin (this volume) and Paris et al. (this volume, a, b); therefore only a brief description is given herein.

The Ordovician and lowermost Silurian succession of the Qusaiba-1 section is composed of shales, siltstones and sandstones. The shallow core hole with a total depth of $551.0 \mathrm{ft}$ (ca 168 m) went through the shales of the Qusaiba Member, Qalibah Formation, for $257 \mathrm{ft}$ (ca. $78 \mathrm{~m}$ ) and penetrated the underlying Ordovician strata for $294 \mathrm{ft}$ (ca. $90 \mathrm{~m}$ ). The local Upper Ordovician succession includes the glacially related sediments of the Sarah Formation (from bottom to top: Sarah Sandstone, Baq'a Shale and Baq'a Sandstone), and the alternating shales and sandstones of the Quwarah Member in the upper part of the Qasim Formation (Fig. 2). 
According to Melvin (this volume) the Quwarah Member was deposited in a proximal prodelta to distal delta front. This member ends with a prograding shoreface sequence unconformably overlain by the Sarah Formation, which begins with a basal disrupted facies (glaciotectonic unit) corresponding to the lower part of the Sarah Sandstone Member. The main sandy part of the Sarah Sandstone Member represents gravity flow deposits. The Baq'a Shale Member begins with stratified diamictites, interpreted as resulting from the final melting of the Gondwana ice sheets. The Sarah Formation ends with the Baq'a Sandstone Member representing delta-front sandy deposits abruptly overlain by high energy fluvial sediments (Melvin, this volume). This fluvial sequence is likely related to the post glacial isostatic uplift described by Melvin and Miller (2009).

Chitinozoan biostratigraphy implies that the Katian-Hirnantian boundary lies within the uppermost Quwarah Member, coinciding with Ancyrochitina merga and Tanuchitina elongata chitinozoan biozones. The Sarah Formation represents the Hirnantian. The basal part of the Qusaiba Member is referred to the earliest Rhuddanian, whereas the main part of the latter member corresponds to the mid Aeronian (Paris et al., this volume, b).

\section{Material and methods}

For organic-walled microfossils only shales and siltstones were sampled. The bulk samples, 8-60 g in size, were provided to FP for chitinozoan study by the Saudi Arabian Oil Company (Saudi Aramco). On average 6-10 g of each sample were processed for palynomorph extraction using standard $\mathrm{HCl}$ and $\mathrm{HF}$ treatment in the palynological laboratory of Rennes 
University. Microfossils, mostly chitinozoans, were hand-picked and mounted on permanent palynological slides. The remaining sample residues were kept in distilled water for future analysis. For full methodological details see Paris (1981) and Paris et al. (this volume, a).

In search for scolecodonts, chitinozoan slides from 20 samples were examined and 14 of them turned productive. The jaws mounted on slides were photographed under a Leica optical microscope in Rennes University. Additionally the residues of six samples were re-picked for scolecodonts under a stereo-microscope. Scolecodonts were common or abundant only in three of the residues studied. Altogether the collection contains ca 100 individual diagnostic jaws, a few fused jaws and one jaw apparatus, not counting fragments and various nondiagnostic smaller elements (the total number of scolecodonts is about 200).

The picked specimens were stored in glycerine and studied according to the methods described by Hints (1998). Scolecodonts were photographed using a Nikon AZ-100 optical microscope equipped with digital microscope camera in Tallinn University of Technology. In order to achieve acceptable depth-of-focus, z-stacks of 2-10 images were taken of most specimens and then digitally combined using the Combine ZM software. Scanning electron microscopy was not used due to the fragile nature of most specimens and the risk of breaking them during drying and mounting.

The Qusaiba-1 core is held by the Saudi Arabian Oil Company and the chitinozoan slides and sample residues are kept at the Rennes University. The collection of scolecodonts picked from the residues, which forms the basis of this report, is deposited at the Institute of Geology, 
Tallinn University of Technology (institutional abbreviation GIT), under the collection number 641.

\section{Previous record of scolecodonts from Gondwana}

Published records on Ordovician scolecodonts from Gondwana, and various peri-Gondwanan terranes, are few and scattered. So far the only paper where apparatus-based classification is used is that by Whittle et al. (2008). Those authors studied bedding plane scolecodont clusters from the Late Ordovician (Hirnantian) Soom Shale Lagerstätte of South Africa and recorded a low-diversity assemblage of probable mochtyellids and xanioprionids (Synaptogenys and Xanioprion?). Other records on Ordovician scolecodonts from Gondwana are based either on single-element-taxa, or simply mention the occurrence of scolecodonts without any taxonomic approach.

Taugourdeau (1976), summarizing data on single-element-based taxa worldwide, mentioned the occurrence of several species in the Ordovician of North Africa (Sahara), most of them assigned to Eunicites, Lumbriconereites, and Staurocephalites. These generic names are, however, problematic (Jansonius and Craig, 1971; Eriksson et al., 2004) and the specimens assigned to these taxa are difficult to bind to modern apparatus-based classification without re-examination of the original collections. Without trying to identify individual taxa, the occurrence of scolecodonts has been reported from North Africa by Bourahrouh et al. (2004). Those authors discussed frequency changes together with other acid-resistant microfossils. 
Ordovician scolecodonts are also known from Australia. Combaz (1965, pl. 1:13) figured one maxilla of Oenonites or Protarabellites from Queensland. More recently Furey-Grieg (1999) illustrated a small collection from the Upper Ordovician Wisemans Arm Formation, eastern Australia, containing a possible kalloprionid jaw, a maxilla resembling those of mochtyellids ("Mochtyella fragilis group") and several less diagnostic jaws, some of which represent placognath apparatus type. The occurrence of Middle Ordovician scolecodonts from western Australia was reported by Winchester-Seeto et al. (2000), but they neither described nor figured any specimens.

Khanna (1983) reported scolecodonts from the Late Ordovician to early Silurian Pin Dolomite of Spiti Valley, Himalaya. Their poor preservation does not allow species-level identifications, but the occurrence of paulinitids and possibly mochtyellids can be established. An unpublished collection of Thomas Suttner, University of Graz, contains also a ramphoprionid jaw from the Ordovician of the same area.

Bassett et al. (2004) mentioned the occurrence of Late Ordovician scolecodonts in east-central Iran. Ordovician scolecodonts have also been collected, and partly studied as a $\mathrm{PhD}$ project, from the Alborz Range, northern Iran (Ghavidel-syooki, personal communication, 2004). The latter collection contains some species that are similar to, and possibly conspecific with the Baltic taxa. Good preservation and diversity of scolecodonts show potential for a detailed taxonomic study; hitherto, however, only an abstract has been published based on that material (Kazemi, 2009). 
Paris and Deunff (1970, pl. 1:16) figured a probable paulinitid jaw, assigned to Leodicites from Mid Ordovician strata of Roche-au-Merle, Ille-et-Vilaine, France, representing the Armorican block of Gondwana (or peri-Gondwana). A few Ordovician scolecodonts are known also from the Prague Basin, Perunica, which was part of Gondwana until the Early Ordovician and probably constituted a small separate terrane later in the Ordovician and Silurian (Cocks and Torsvik, 2004). Šnajdr (1951, pl. 7:2-5) illustrated several maxillae from the lower Darriwilian Šarka Formation, assigned to "Polychaeta indet. species B". Those jaws definitely represent different species, possibly including atraktoprionids, ramphoprionids, and/or some unknown groups. Restudy of the material is necessary for confirmation, but if a ramphoprionid and atraktoprionid affinity is proven, this would comprise the oldest known record of these families. Other material described by Šnajdr (1951) comes from the Late Ordovician Králùv Dvùr and Kosov formations where rare Kettnerites hebes and jaws of uncertain taxonomic affinity (assigned to Staurocephalites) occur. The paulinitid affinity of K. hebes may, however, be questioned based on the illustration (Šnajdr, 1951, pl. 6:12). In addition, a few scolecodonts, including one specimen most probably belonging to ramphoprionids, have been collected from the Late Ordovician Kosov Formation $(\mathrm{OH}$ unpublished data). Silurian scolecodonts from Prague Basin have been recently published by Tonarova et al. (2012).

Ordovician scolecodonts have never been described before from the Arabian Peninsula, but their presence in palynological samples has been noted by several authors (e.g., Stump et al., 1995; Strother et al., 1996; Al-Ghammari, 2010; Rickards et al., 2010). 
In summary, the previous data on Ordovician scolecodonts from Gondwana are few and mostly lack proper taxonomic basis. It is evident that many families common on Baltica and Laurentia were also widespread on Gondwana (particularly polychaetaspids, paulinitids and mochtyellids, but also atraktoprionids, ramphoprionids and xanioprionids). However, much more first-hand data are needed to understand the distribution of scolecodonts and evaluate their stratigraphic utility. New data from the Qusaiba-1 core hole therefore comprise a valuable addition to the previous data set and encourage further efforts to study scolecodonts alongside other palynomorphs in Gondwanan successions.

\section{Scolecodonts from the Qusaiba-1 core hole}

Preservation of the material is relatively good in the Qasim Formation and basal Sarah Formation, even though most specimens display microscopic fractures (e.g., Plate III, 14-19), many are broken (Plate III, 1, 28) and some are compressed. Preservation is worse in the upper Sarah and Qalibah formations. Most specimens are yellow to brown and partly translucent. Their average size is ca 350 microns (70 specimens measured in the richest sample from $497.8 \mathrm{ft}$ ), which is notably smaller than usually encountered in Katian and Hirnantian strata of Baltica and Laurentia (Hints, 2000; Eriksson and Bergman, 2003; OH unpublished data). Whether such small size is a character of the taxa recovered or reflects stressed environment, post-mortem sorting or methodological bias remains presently unknown.

The abundance of scolecodonts is highly variable. The yield was very low, or the samples were barren, in the basal Qusaiba Member (Rhuddanian) and in the Baq'a Shale Member 
(Hirnantian). In contrast, all samples from the Quwarah Member and basal Sarah Formation were productive and three samples from this interval turned to be rich in scolecodonts. The richest sample from $497.8 \mathrm{ft}$ contained 73 posterior maxillae, not counting smaller undiagnostic jaws and fragments. Considering that only $10 \mathrm{~g}$ of rock were processed, the abundance appears to be particularly high, 7,300 specimens per $\mathrm{kg}$ (abundance of scolecodonts is commonly calculated per $\mathrm{kg}$, as is the case of conodonts). The previous records from the Baltic Late Ordovician have rarely revealed more than 1,000 specimens per kg (Hints, 2000; Hints et al., 2010), and similar abundance is typical of Laurentia (Eriksson and Bergman, 2003). Exceptional abundance of scolecodonts reaching over 7,000 specimens/kg was recently reported from the middle Silurian of Gotland (Calner et al., 2008), being in par with the counts from the Qusaiba-1 sample. Thus the latter represents one of the highest scolecodont concentrations ever recorded, and definitely the richest sample published from Gondwana so far (unpublished data by FP indicate even higher concentrations from the Silurian and Devonian of Behemia).

For proper genus- and species level taxonomy individual scolecodonts need to be viewed as belonging to complex jaw apparatuses, composed of two to more than ten major element types (see Szaniawski, 1996 for review of apparatus types). Finds of complete jaw apparatuses are generally rare. In the Qusaiba-1 samples only one such apparatus (Kettnerites sp.) has been found, but since it was permanently mounted on a slide, detailed examination was not possible. Apparatuses can also be reconstructed using morphological criteria (size, symmetry, type of denticulation etc), frequency ratios of different jaws, and knowledge on related taxa. Due to the small size of the collection at hand, the state of preservation, rather wide variability of some species, and the scarcity of previous knowledge from Gondwana, 
apparatus reconstructions were only partly possible in case of the Qusaiba-1 material. We therefore conclude that more material is necessary for thorough systematic approach and use open nomenclature in the discussion below.

The entire assemblage contains at least 11 , and possibly up to 15 different species. In the richest sample from $497.8 \mathrm{ft}$ at least 10 species occur. While this number is the highest for Gondwana, twice as high species diversity is typical of the Baltic late Katian samples. Indeed, many rare species in the Qusaiba-1 succession probably remain unknown due to small sample size.

Most of the species recovered belong to the families Ramphoprionidae, Paulinitidae, Polychaetaspidae and Atraktoprionidae (Plates I-III) that are further discussed below. A very low proportion of taxa with placognath-type jaw apparatuses is a particular characteristic of the Qusaiba assemblage.

\subsection{Polychaetaspidae}

Polychaetaspids constitute the most common and species-rich family in the Paleozoic, with Oenonites being a globally distributed genus that ranges from the Ordovician to Permian. In the Qusaiba-1 collection Oenonites is identified throughout the section and represented by at least two different species. These are tentatively denoted as Oenonites sp. 1 and Oenonites sp. 2 (Fig. 2, Plate I, 1-8, 10), differing from each other primarily by the shape of outer faces of the posterior maxillae. 
Reconstructions of polychaetaspid jaw apparatus remain nevertheless tentative for the time being. In case of limited material it may be difficult to distinguish right MI jaws of Oenonites from those of Gen. et sp. indet. 1 of ramphoprionid affinity (Plate I, 9), especially if the specimens are small, flattened or broken. Other polychaetaspid jaws recovered include basal plates (Plate I, 26), carriers (Plate I, 3-23) and anterior maxilla (Plate I, 15). One basal plate (Plate I, 20) reminds also of that of Kozlowskiprion, another polychaetaspid genus, but without the posterior maxillae positive identification of the genus cannot be made. The polychaetaspid jaws, which could not be assigned to either above tentative species, were recorded simply as Oenonites spp. in Figure 2. In the sample $497.8 \mathrm{ft}$ Oenonites accounts for nearly $20 \%$ of the specimens.

Another polychaetaspid, supposedly representing a new genus, is denoted here as Gen. et sp. indet. 2 (Plate 1, 12). A single right MI of this species has been found from sample $497.8 \mathrm{ft}$. A specific type of denticulation suggests that the basal plate illustrated on Plate I, 21 may also belong to the same species.

\subsection{Ramphoprionidae}

More than half of the scolecodonts in the sample $497.8 \mathrm{ft}$ belong to a taxon denoted here as Gen. et sp. indet 1 (Plate II). It is characteristic also in other samples from the Quwarah Member and basal Sarah Formation, but was not recorded in the overlying strata. The apparatus of Gen. et sp. indet. 1 can be reconstructed partly. There is good quantitative and morphological basis for matching the left and right posterior maxillae. The anterior maxillae (MII; Plate II, 15-27) fit nicely with the posterior jaws based on the size and type of 
denticulation. The possible carriers of Gen. et sp. indet. 1 are illustrated on Plate III, 25. The morphology of the basal plate is unknown, although this jaw may, too, be present in the collection studied. The morphological variability of Gen. et sp. indet. 1 seems to be rather wide or, alternatively, it embraces two separate species. The answer to this question is nevertheless pending further well-preserved material.

This taxon is unknown in the Baltic Ordovician, but closely similar and likely congeneric forms are recorded from the Late Ordovician of Laurentia. Eriksson and Bergman (2003) denoted it as Incertae familiae Gen. et sp. indet. A, observing its similarities with ramphoprionids, polychaetaspids and kalloprionids. Herein we support the ramphoprionid affinity based on several morphological criteria. First, the left MI has short posterior margin, which is lacking in polychaetaspids. Kalloprionids, on the other hand, have longer posterior margin and usually longer inner wing in left MI. The MII jaws of Gen. et sp. indet. 1 are elongated, with clearly differentiated dentaries, similar of which are typical of some ramphoprionids. The morphology of the carriers supposedly belonging to Gen. et sp. indet. 1 fits also well with those of ramphoprionids.

In addition to Gen. et sp. indet. 1, the Qusaiba-1 collection includes a single right MI (Plate II, 14) from sample $497.8 \mathrm{ft}$, which probably belongs to another genus of ramphoprionids.

\subsection{Paulinitidae}

Paulinitids constitute an important component of the Qusaiba-1 polychaete fauna. Represented only by the genus Kettnerites, paulinitids occur throughout the section and 
account for $14 \%$ of specimens in the richest sample. The material includes left and right posterior maxillae and several left MII elements. The right MII elements, which according to Bergman (1989) are the most diagnostic ones, were not recovered, or could not be recognised. It is therefore difficult to characterise the species and compare it with paulinitids from other regions. The species is, however, different from most Silurian paulinitids described from Gotland (Bergman, 1989) and the Late Ordovician Kettnerites sylvanensis from Laurentia (Eriksson et al., 2005), in having less differentiated dentary on the left MII. Paulinitid jaws found from the Hirnantian of Baltica ( $\mathrm{OH}$ unpublished collection) seem to be morphologically closer to the Qusaiba-1 material, but this comparison awaits further material from both regions.

\subsection{Atraktoprionidae and Kalloprionidae}

Atraktoprionids are relatively abundant in the Qusaiba-1 section, accounting for $11 \%$ of specimens in the sample $497.8 \mathrm{ft}$. This family is represented by at least three different species of Atraktoprion, distinguished from each other by the length of dentaries and size of hooks in the posterior maxillae. Since apparatus reconstructions of atraktoprionids remain tentative, the left MI jaws are here used for differentiating the species. Several anterior maxillae of atraktoprionid affinity have also been recovered (Plate III, 21-22, 24, 28), but they cannot be confidently matched with the posterior maxillae. Possibly some of the basal plates in the collection also belong to atraktoprionids. Atraktoprionid jaws which could not be assigned to any of the species below are treated as Atraktoprion spp. 
Atraktoprion sp. 1 (Plate III, 12, 18-19) is characterised by relatively long dentaries and shorter hooks. In the left MI the hook represents about 1/3 of jaw length. The probably matching right MI jaws with correspondingly short hooks are found from samples 484.7 and $497.8 \mathrm{ft}$.

Atraktoprion sp. 2 (Plate III, 14-15, 17, 20) is identified only from sample $497.8 \mathrm{ft}$. It is similar to Atraktoprion sp. 1, but the hook in left MI is longer, corresponding to about half of jaw length. The right MI is insufficiently known; only a single specimen probably belonging to this species has been found (Plate III, 20). Atraktoprion sp. 2 is similar to A. major known from the Baltic area (Hints, 1998, fig. 16H-K), except that the maximum width of left MI is located more anteriorly.

Atraktoprion sp. 3 (Plate III, 16) differs from the other species in having the longest hook (2/3 of jaw length), considerably shorter dentary and convex instead of concave postero-lateral margin in the left MI. Only a single left MI of this species is known from the sample $497.8 \mathrm{ft}$. Additionally a right MI of Skalenopron has been identified from the Ordovician part of the Qusaiba section in the sample $476.7 \mathrm{ft}$. Skalenoprion differs from Atraktoprion in having the basal plate fused with right MI forming a compound jaw. Although Kielan-Jaworowska (1966) erected the family Skalenoprionidae, we herein consider Skalenopron as belonging to the Atraktoprionidae. In Baltic latest Ordovician Skalenopron is very rare, becoming more frequent in Silurian strata.

Identification of kalloprionids in the Qusaiba assemblage is tentative, based on a single right MI of Kalloprion? from the sample $497.8 \mathrm{ft}$ (Plate III, 23). 


\subsection{Other scolecodonts}

In addition to the above discussed taxa the collection contains several scolecodonts that presently cannot be assigned to particular family. This concerns, for instance, some of the basal plates, anterior maxillae and carriers. Their labidognath or prionognath affinity can be recognised, but they cannot be unambiguously matched with other apparatus elements. Hence it is possible that they belong to some of the species mentioned above, or represent taxa whose other elements are not present in the collection studied.

Species with placognath-type apparatuses need special mentioning. They are extremely rare in the Qusaiba-1 collection. A single left MI of placognath type was recovered from the sample $497.8 \mathrm{ft}$ (Plate III, 29). It is a simple straight jaw with one denticulated ridge. Similar jaws are present in certain mochtyellids, but also in some xanioprionids. Another probable placognath fragment, not identified more precisely, is shown on Plate III, 30.

Possibly of placognath type is also the left maxilla (MI or MII) figured on Plate I, 16. Its general shape reminds of those of mochtyellids or some probable tetraprionids known from the Baltic Silurian (see Hints et al. 2006, pl. 2:5). However, it has a well-developed shank, which is atypical of the hitherto known placognath and ctenognath taxa.

Regarding the placognath forms, it should be stressed that their family- and genus-level classification is not well established. Unpublished collections from the Baltic Ordovician and Silurian indicate that numerous genera and possibly some families have yet to be formally 
described. It is very likely that the placognath jaws from the Qusaiba-1 section represent also new genera, which, indeed, cannot be described before more material becomes available.

\section{Discussion and conclusions}

This study is among the first steps in describing the Ordovician scolecodonts from the Gondwanan realm. As such, there are few previous data to compare the current results with and it would be premature, for instance, to draw any conclusions about their stratigraphic utility. Moreover, the collection is relatively small and stratigraphically restricted. That being said, the Qusaiba-1 scolecodonts still deserve further discussion and two aspects are of particular interest: first, how to interpret the observed local distribution pattern, and second, how the Qusaiba assemblage compares with the coeval polychaete faunas of other paleocontinents.

\subsection{Notes on distribution}

Within the Ordovician part of the succession the distribution and abundance patterns of scolecodonts appeared to be in good accordance with chitinozoan data presented by Paris et al. (this volume, a). The Quwarah Member and the basal disrupted facies of the Sarah Formation contain very similar polychaete fauna, corresponding to the chitinozoan assemblage 3 of Paris et al. (this volume, a). It is interesting to note that the sample from $497.8 \mathrm{ft}$, richest in scolecodonts, shows also the highest concentration of chitinozoans within the Ordovician part of the Qusaiba-1 section (1167 vesicles / g; Paris et al., this volume, a). 
Similarly the second richest scolecodont sample from $484.7 \mathrm{ft}$ is also the second richest for chitinozoans (696 vesicles / g). Whilst this may indicate especially favourable conditions for both groups, it is more likely that these samples correspond to more condensed strata and/or indicate post-mortem sorting and concentration of palynomorphs. Scolecodonts were not studied in the basal sample from the Quwarah Member (551.0 ft), thus it remains unknown if a distinct polychaete fauna would correspond to the chitinozoan assemblage 4 of Paris et al. (this volume, a). Overall, the latest Katian and/or earliest Hirnantian delta-related shelf environments in the present-day Arabian Peninsula constituted a suitable habitat for jawbearing polychaetes. The taxonomic composition and state of preservation of chitinozoans in the Baq'a Shale suggest reworking from Middle and early Late Ordovician strata (assemblage 2 of Paris et al., this volume, a). Scolecodonts in this interval are similarly poorly preserved, their abundance is low, and typical elements of the Quwarah and basal Sarah assemblage, particularly the dominant Gen. et sp. indet. 1 and atraktoprionids, are not recorded. Although no distinct Middle or early Late Ordovician taxa could be identified, preservation and abundance of scolecodonts support the interpretation of Paris et al. (this volume, a). In the Silurian part of the succession scolecodonts and chitinozoans display notably different patterns. Chitinozoans are characterised by the disappearance of Ordovician taxa and appearance of several new species in the basal beds of the Qusaiba Member (Paris et al., this volume, b). Scolecodonts, in contrast, are very rare and only few long-ranging taxa were identified. In addition to the collection of scolecodonts discussed in this paper, a separate set of Silurian chitinozoan slides was inspected also for scolecodonts (by OH, slides in Rennes University). Out of 24 samples from the Qusaiba Member (interval 132.05-251.1 ft), two turned productive, and altogether only three scolecodonts were recognised, belonging to Kettnerites? and Skalenoprion. 
One may argue that the scarcity of scolecodonts in the basal Silurian strata directly reflects the impact of Hirnantian extinction. However, scolecodonts represent fossils of benthic organisms that were facies controlled(Eriksson et al. 2004 and references therein). Hints (2000), analysed the spatial distribution of late Katian jawed polychaete faunas of the Baltoscandian paleobasin and found that both abundance and diversity decrease notably towards the deeper shelf settings. A similar trend was outlined in Gondwana by Al-Ameri (1983), who used scolecodonts together with chitinozoans, acritarchs and spores to distinguish Silurian palynofacies in Libya. The latter author concluded that scolecodonts characterise lagoonal and intermediate facies, being less abundant or lacking in deeper water, open marine settings. Hence the low abundance and diversity of scolecodonts in the Qusaiba Member probably indicate less favourable (deeper shelf) conditions for polychaetes. This fits well with the sedimentological interpretation of the Qusaiba-1 succession (Melvin, this volume).

\subsection{Comparison with coeval polychaete faunas}

Katian jawed polychaete faunas are thoroughly studied in the Baltic area (Hints, 2000, 2001; Eriksson and Hints, 2009; Hints et al., 2010). Scolecodonts are well documented also from the mid-continent Laurentia (Eriksson and Bergman, 2003), making this interval the best known Paleozoic time bin with regard to polychaete biogeography. The fauna described in this paper has potential to extend the previous biogeographical analysis (Hints and Eriksson, 2007a); however, the first question to ask is if the Qusaiba-1 assemblage represents a geographically restricted fauna or is it characteristic of wider areas within Gondwana. 
A small unpublished collection of Late Ordovician palynomorphs from drill cores of Libya (collection of FP, Rennes University, studied by $\mathrm{OH}$ ), containing ca 60 scolecodonts and jaw fragments, provides some insights into this question. The two most common taxa identified in the Libyan collection were Oenonites sp. and Kettnerites sp., but Gen. et sp. indet. 1, dominating in the Qusaiba-1 section, was also present in several samples. Additionally Protarabellites?, Lunoprionella, and few placognath jaws were recognised. Overall the assemblage is very similar to that from the Qusaiba-1 core, except that atraktoprionids are missing and taxa with placognath apparatus seem to be slightly more common. This suggests that the Qusaiba-1 assemblage could be used as a rough proxy for the latest Ordovician of northern Gondwana, not just for a single locality or the Arabian Peninsula. The faunas of the entire supercontinent were most likely more complex (cf. discussion on previous record on scolecodonts from Gondwana above)

Hints and Eriksson (2007a) summarised the distribution and diversification of Ordovician jaw-bearing polychaetes. Their biogeographical analysis was based on limited material except for Baltica and mid-continent Laurentia. Detailed comparison of the Late Ordovician faunas of these two regions revealed that few species but most genera were common to both continents. However, Hints and Eriksson (2007a) highlighted also several differences. First, the Baltic faunas throughout the Katian, and especially in the late Katian, had significant proportion of taxa with placognath-type jaw apparatus, Mochtyellidae and Xanioprionidae in particular. The Laurentian faunas, in contrast, had very few placognath taxa and their proportion in late Katian faunas was only few per cents. The polychaeturids, which constituted a characteristic component of the Baltic faunas, were virtually missing in 
Laurentia (Hints and Eriksson, 2010). On the other hand, the paulinitids, ramphoprionids, kalloprionids, atraktoprionids and what Eriksson and Bergman (2003) called Incertae familiae (herein interpreted as a group of ramphoprionids) flourished in Laurentia.

The first observation regarding the Qusaiba-1 assemblage is that it is notably less diverse than the coeval faunas documented from Baltica and Laurentia, containing perhaps 15 species against many tens. To a large degree this can be attributed to small sample size from the Qusaiba-1 core hole, which fails to reveal less frequent taxa. The maximum abundance of scolecodonts recorded in the Qusaiba-1 sample $497.8 \mathrm{ft}$ (7,300 specimens per $\mathrm{kg}$ ) has, however, no match in Baltica or Laurentia. Hints (2000) reported a maximum of less than 500 specimens per $\mathrm{kg}$ in the latest Katian and Hints et al. (2010) counted up to about 2,000 per kg in the Hirnantian (note that the numbers are approximate because the initial calculations were made differently from the present study).

With respect to taxonomic composition, most species found from the Qusaiba-1 core belong to cosmopolitan genera, in particular Oenonites, Atraktoprion, Kettnerites, Skalenoprion, and Kalloprion. Concerning the unpublished Libyan data, Protarabellites and Lunoprionella may be added to the list of northern Gondwanan taxa that occur in other continents. The dominant species in the Qusaiba-1 assemblage, Gen. et sp. indet. 1, needs special mentioning: supposedly congeneric forms occur in Laurentia, but are presently unknown from elsewhere. In turn, many genera that are common in Baltica and/or Laurentia, were not recorded in the Qusaiba-1 samples. 
In order to visualise comparison, the family-level assemblage structure of the richest sample from $497.8 \mathrm{ft}$ was plotted against averaged late Katian data from Baltica and Laurentia (Fig. 3; Baltic and Laurentian data from Hints and Eriksson, 2007a). It appears that the Qusaiba-1 assemblage is more similar to Laurentian than Baltic fauna.

Both the Qusaiba-1 and Laurentia are characterised by notable share of paulinitids, atraktoprionids and ramphoprionids, while the percentage of placognath/ctenognath taxa is very low. Laurentian and northern Gondwanan similarity is further backed by the occurrence of Gen. et sp. indet. 1 of ramphoprionid affinity. The Baltic faunas, in contrast, are characterised by high relative frequency of various placognath taxa (e.g., Pistoprion, Mochtyella, Xanioprion, Rhytiprion, Rakvereprion), some of which seem to be endemic to Baltica. Paulinitids (Kettnerites) are generally very rare on Baltica, and ramphoprionids and atraktoprionids are seldom abundant in the latest Ordovician strata. Distinct for Baltica is also the occurrence of polychaeturids (Pteropelta).

The Baltic and Laurentian latest Ordovician polychaete faunas both derive from low-latitude shallow carbonate shelves, much different from the environments of northern Gondwana. Also, Baltica and Laurentia were located closer to each other at that time (e.g., Cocks and Torsvik, 2004). The above described pattern suggests, however, a closer link between the polychaete faunas of northern Gondwana and Laurentia than between Laurentia-Baltica or Gondwana-Baltica. This is different from what could be expected and what has been observed in case of most other fossil groups, including chitinozoans (Paris, 1990; Vandenbroucke et al., 2010) and cryptospores (Vecoli et al., 2011) among palynomorphs. 
Based on contrasting properties for paleogeographic distribution Cocks and Fortey (1990) identified three broad categories: cratonic benthic faunas, epiplanktic organisms and deep benthic forms. Most Paleozoic jaw-bearing polychaetes would be assigned to the first of these groups, whose paleogeographic dispersal is limited mainly to the same paleocontinent. This does not explain well the Laurentia-Gondwana link suggested by the Qusaiba-1 assemblage and other northern Gondwanan scolecodonts.

It may be argued that perhaps oceanic circulation was responsible for the observed anomalous pattern and/or some characters specific to polychaetes played an important role. In order to build more conclusive argumentation, however, additional first-hand data are needed from the Middle and Upper Ordovician of different parts of Gondwana, as well as from Laurentia. Relatively good preservation revealed in the Qusaiba-1 section and some of the highest concentrations of scolecodonts ever recorded indicate good potential for continuing scolecodont studies on the Arabian Peninsula. With sufficient background information scolecodonts could turn more useful also for biostratigraphy and biofacies analysis.

\section{Acknowledgements}

We are grateful to the Saudi Arabian Ministry of Petroleum and Mineral Resources and the Saudi Arabian Oil Company (Saudi Aramco) for granting permission to use the material and publish this paper. We thank Mats E. Eriksson (Lund Univesity) and an anonymous referee for their suggestions to improve the manuscript, and Bernard Owens who initiated the very first steps of the CIMP/Aramco research project. $\mathrm{OH}$ work was financially supported by the 
Estonia Research Council (project SF0140020s08). This study is a contribution to IGCP project 591 "The Early to Middle Paleozoic Revolution".

\section{References}

Al-Ameri, T.K., 1983. Acid-resistant microfossils used in the determination of Paleozoic palaeoenvironments in Libya. Palaeogeography, Palaeoclimatology, Palaeoecology 44, 103-116.

Al-Ghammari, M., Booth, G.A., Paris, F., 2010. New chitinozoan species from the Saih Nihayda Formation, Middle Ordovician of the Sultanate of Oman. Review of Palaeobotany and Palynology 158, 250-261.

Bassett, M.G., Dastanpour, M., Popov, L.E., 2004. Late Ordovician faunas of Kerman Province, east-central Iran. In: Hints, O., Ainsaar, L. (Eds.), WOGOGOB-2004 Conference Materials. Tartu University Press, Tartu, pp. 43-44.

Bergman, C.F., 1989. Silurian paulinitid polychaetes from Gotland. Fossils and Strata 25, 1128.

Bourahrouh, A., Paris, F., Elaouad-Debbaj, Z., 2004. Biostratigraphy, biodiversity and palaeoenvironments of the chitinozoans and associated palynomorphs from the Upper Ordovician of the Central Anti-Atlas, Morocco. Review of Palaeobotany and Palynology 130, 17-40.

Calner, M., Eriksson, M.E., Clarkson, E.N., Jeppsson, L., 2008. An atypical intra-platform environment and biota from the Silurian of Gotland, Sweden. GFF 130, 79-86. 
Cocks, L.R.M., Fortey, R.A., 1990. Biogeography of Ordovician and Silurian faunas. In: McKerrow, W.S., Scotese, C.R. (Eds.), Palaeozoic Palaeogeography and Biogeography. Geological Society of London Memoirs 12, 97-104.

Cocks, L.R.M., Torsvik, T.H., 2004. Major terranes in the Ordovician. In: Webby, B.D., Paris, F., Droser, M.L., Percival, I. (Eds.), The Great Ordovician Biodiversification Event. Columbia University Press, New York, pp. 61-67.

Combaz, M.A., 1965. Un microbios a Chitinozoaires dans le Paléozoique du Queensland (Australie). C. R. Acad. Sc. Paris 260, 3449-3451.

Eriksson, M., Bergman, C.F., 2003. Late Ordovician jawed polychaete faunas of the type Cincinnatian region, U.S.A. Journal of Paleontology 77, 509-523.

Eriksson, M.E., Hints, O., 2009. Vagrant benthos (Annelida; Polychaeta) associated with Upper Ordovician carbonate mud-mounds of subsurface Gotland, Sweden. Geological Magazine 146, 451-462.

Eriksson, M.E., Bergman, C.F., Jeppsson, L., 2004. Silurian scolecodonts. Review of Palaeobotany and Palynology 131, 269-300.

Eriksson, M.E., Leslie, S.A., Bergman, C.F., 2005. Jawed polychaetes from the upper Sylvan shale (Upper Ordovician), Oklahoma, USA. Journal of Paleontology 73, 486-496.

Furey-Greig, T., 1999. Initial report on discovery of Ordovician scolecodonts from eastern Australia. Proceedings of the Linnaean Society of New South Wales 121, 85-88.

Hints, L., Hints, O., Kaljo, D., Kiipli, T., Männik, P., Nõlvak, J., Pärnaste, H., 2010. Hirnantian (latest Ordovician) bio- and chemostratigraphy of the Stirnas-18 core, western Latvia. Estonian Journal of Earth Sciences 59, 1-24. 
Hints, O., 1998. Viruan jawed polychaetes from Estonia and St. Petersburg region. Acta Paleontologica Polonica 43, 471-516.

Hints, O., 2000. Ordovician eunicid polychaetes of Estonia and surrounding areas: a review of their distribution and diversification. Review of Palaeobotany and Palynology 113, $41-55$.

Hints, O., 2001. Distribution of scolecodonts. In: Põldvere, A. (Ed.), Estonian Geological Sections. Bulletin 3. Valga (10) drill core. Geological Survey of Estonia, Tallinn, pp. $12-14$.

Hints, O., Eriksson, M.E., 2007a. Diversification and biogeography of scolecodont-bearing polychaetes in the Ordovician. Palaeogeography, Palaeoclimatology, Palaeoecology $245,95-114$.

Hints, O., Eriksson, M.E., 2007b. Biogeography of Ordovician and Silurian jaw-bearing polychaetes. Acta Palaeontologica Sinica 46(Suppl.), 181-187.

Hints, O., Eriksson, M.E., 2010. Ordovician polychaeturid polychaetes: Taxonomy, distribution and palaeoecology. Acta Palaeontologica Polonica 55, 309-320.

Hints, O., Paris, F., Al Hajri, S., 2008. Discovery of Late Ordovician scolecodonts from the Qusaiba-1 core hole, Arabian Peninsula, and its palaeobiogeographical implications. In: 12th International Palynological Congress and 8th International Organisation of Palaeobotany Conference. Aug. 30-Sept. 5, 2008. Abstract Volume. Bonn. Terra Nostra v. 2008(2), 117-118.

Hints, O., Eriksson, M., Högström, A.E.S., Kraft, P., Lehnert, O., 2004. Chapter 23. Worms, Worm-like and Sclerite-Bearing Taxa. In: Webby, B.D., Paris, F., Droser, M.L., 
Percival, I. (Eds.), The Great Ordovician Biodiversification Event. Columbia University Press, New York, pp. 223-230.

Hints, O., Killing, M., Männik, P., Nestor, V., 2006. Frequency patterns of chitinozoans, scolecodonts, and conodonts in the upper Llandovery and lower Wenlock of the Paatsalu core, western Estonia. Proceedings of the Estonian Academy of Sciences, Geology 55, 128-155.

Jansonius, J., Craig, J.H., 1971. Scolecodonts: I - Descriptive terminology and revision of systematic nomenclature; II. Lectotypes, new names for homonyms, index of species. Bulletin of Canadian Petroleum Geology 19, 251-302.

Kazemi, A., 2009. Scolecodonts/biostratigraphy. Geological Society of America Abstracts with Programs 41, 15.

Khanna, A.K., 1983. Scolecodonts from Late Ordovician - Early Silurian sequence of Spiti Valley, Tethys Himalaya. In: Proceedings of Fifth Indian Geophytological Conference. The Palaeobotanical Society, Lucknow, pp. 24-28.

Kielan-Jaworowska, Z., 1966. Polychaete jaw apparatuses from the Ordovician and Silurian of Poland and comparison with modern forms. Palaeontologia Polonica 16, 1-152.

Melvin, J., (this volume). Lithostratigraphy and depositional history of Upper Ordovician and lowermost Silurian sediments recovered from the Qusaiba-1 shallow core hole, Qasim region, central Saudi Arabia. Review of Palaeobotany and Palynology.

Melvin, J., Miller, M., 2009. Re-advance, retreat and rebound: stratigraphic response of the Sarah Formation (Hawban and Baq'a members) to the demise of the Late Ordovician (Hirnantian) glaciation in central Saudi Arabia. In: Glaciogenic Reservoirs and 
Hydrocarbon Systems, Conference Abstract Volume. Geological Society of London, London, pp. 62-63.

Paris, F., 1981. Les Chitinozoaires dans le Paléozoïque du sud-ouest de l'Europe (cadre géologique - étude systématique - biostratigraphie). Mémoire de la Société géologique et minéralogique de Bretagne 26, 1-496.

Paris, F., 1990. The Ordovician chitinozoan biozones of the Northern Gondwana domain. Review of Palaeobotany and Palynology 66, 181-209.

Paris, F., Deunff, J., 1970. Le paléoplancton Llanvirnien de la Roche-au-Merle. Soc. Géol. Min. de Bretagne Bull. Ser C.2, 25-43.

Paris, F., Verniers, J., Miller, M., Al-Hajri, S., Melvin, J., Wellman, C.H., (this volume, a). Late Ordovician- earliest Silurian chitinozoans from the Qusaiba-1 core hole, (North Central Saudi Arabia) and relation to the Hirnantian glaciation. Review of Palaeobotany and Palynology.

Paris, F., Miller, M., Al-Hajri, S., Zalasiewicz, J., (this volume, b). Early Silurian chitinozoans from the Qusaiba type area, North Central Saudi Arabia. Review of Palaeobotany and Palynology.

Rickards B., Booth, G., Paris, F., Hurst, G., Heward, A., 2010. Marine Flooding Events of the Early and Middle Ordovician of Oman and the U.A.E. and their Graptolite, Acritarch and Chitinozoan Faunas. GeoArabia 15, 81-120.

Šnajdr, M., 1951. On Errant Polychaeta from the Lower Paleozoic of Bohemia. Sbornik Geol. Surv. Czech. Paleontol. 18, 241-296. 
Strother, P.K., Al-Hajri, S., Traverse, A., 1996. New evidence for land plants from the lower Middle Ordovician of Saudi Arabia. Geology 24, 55-58.

Stump, T.E., Al-Hajri, S., Van der Eem, J.G.L.A., 1995. Geology and biostratigraphy of the Late Precambrian through Palaeozoic sediments of Saudi Arabia. Review of Palaeobotany and Palynology 89, 5-17.

Szaniawski, H., 1996. Scolecodonts. In: Jansonius, J., McGregor, D.C. (Eds.), Palynology: Principles and applications 1. American Association of Startigraphic Palynologists Foundation, pp. 337-354.

Taugourdeau, P., 1976. The scolecodonts. Biological memoirs 1, 1-40.

Tonarova, P., Eriksson, M.E., Hints, O., 2012. A jawed polychaete fauna from the late Ludlow Kozlowskii event interval in the Prague Basin (Czech Republic). Bulletin of Geosciences 87, 713-732.

Vandenbroucke, T.R.A., Armstrong, H.A., Williams, M., Paris, F., Zalasiewicz, J.A., Sabbe, K., Nõlvak, J., Challands, T.J., Verniers, J., Servais, T., 2010. Polar front shift and atmospheric $\mathrm{CO} 2$ during the glacial maximum of the Early Paleozoic Icehouse. Proceedings of the National Academy of Sciences 107, 14983-14986.

Vecoli, M., Delabroye, A., Spina, A., Hints, O., 2011. Cryptospore assemblages from Upper Ordovician (Katian-Hirnantian) strata of Anticosti Island, Québec, Canada, and Estonia: palaeophytogeographic and palaeoclimatic implications. Review of Palaeobotany and Palynology 166, 76-93.

Whittle, R., Gabbott, S., Aldridge, R., Theron, J., 2008. Late Ordovician (Hirnantian) scolecodont clusters from the Soom Shale Lagerstätte, South Africa. Journal of Micropalaeontology 27, 147-159. 
Winchester-Seeto, T., Foster, C., Leary, T.O., 2000. The environmental response of Middle Ordovician large organic walled microfossils from the Goldwyer and Nita Formations, Canning Basin, Western Australia. Review of Palaeobotany and Palynology 113, 197-212.

Zalasiewicz, J., Williams, M., Miller, M., Page, M., Blackett, E., 2007. Early Silurian (Llandovery) graptolites from central Saudi Arabia: First documented record of Telychian faunas from the Arabian Peninsula. GeoArabia 12, 15-36. 


\section{Figure captions}

Fig. 1. Location maps for the Qusaiba-1 core hole. (a) Map of the Arabian Peninsula showing the location of the north-western part of the Buraydah quadrangle in Qasim region, central Saudi Arabia (red box). (b) Geological sketch map of the north-western part of the Buraydah quadrangle, showing location of the Qusaiba-1 core hole. Modified after Zalasiewicz et al. (2007).

Fig. 2. Distribution of scolecodonts in the Qusaiba-1 core hole. Lithology and stratigraphy according to Melvin (this volume), chitinozoan biozonation and global correlation after Paris et al. (this volume). Note that Kettnerites and Skalenoprion are recorded in younger Silurian strata. Grey markers indicate unproductive samples; Rhu.=Rhuddanian, Aer.=Aeronian.

Fig. 3. Relative abundance of polychaete families in the richest sample from the Qusaiba-1 core hole (497.8 ft), compared with averaged late Katian data for Laurentia and Baltica (after Hints and Eriksson 2007a, with their Incertae familiae included in the Ramphoprionidae).

\section{Plate captions}

Plate I. Polychaetaspids and other selected scolecodonts from the Upper Ordovician of the Qusaiba-1 core hole. D, V, and W from the basal Sarah Formation ("disrupted facies"), Hirnantian, others from the Quwarah Member of the Qasim Formation, latest Katian or 
earliest Hirnantian. All specimens are in the same scale and in dorsal view unless noted otherwise.

1. Oenonites sp. 1, left MI, GIT641-1, sample 497.8 ft.

2. Oenonites sp. 2, left MI, GIT641-2, sample $497.8 \mathrm{ft}$.

3. Oenonites sp. 2, left MI in outer lateral view, GIT641-3, sample $484.7 \mathrm{ft}$.

4. Oenonites sp. 1, left MI in outer lateral view, GIT641-4, sample $452.75 \mathrm{ft}$.

5. $\quad$ Oenonites sp. 1?, left MI, GIT641-5, sample $497.8 \mathrm{ft}$.

6. Oenonites sp. 2, right MI, GIT641-6, sample $497.8 \mathrm{ft}$.

7. Oenonites sp. 2, right MI, GIT641-7, sample $484.7 \mathrm{ft}$.

8. $\quad$ Oenonites sp., right MI, GIT641-8, sample $497.8 \mathrm{ft}$.

9. Gen et sp. indet. 1?, right MI, GIT641-9, sample $497.8 \mathrm{ft}$.

10. Oenonites sp. 1?, right MI, GIT641-10, sample $497.8 \mathrm{ft}$.

11. Oenonites? sp., broken right MI in half-lateral view, GIT641-11, sample $484.7 \mathrm{ft}$.

12 Gen et sp. indet. 2, right MI, GIT641-12, sample $497.8 \mathrm{ft}$.

13. Oenonites sp., left MI, GIT641-13, sample 484.7 ft.

14. labidognath lateral tooth, GIT641-14, sample $484.7 \mathrm{ft}$.

15. labidognath right anterior maxilla, GIT641-15, sample $497.8 \mathrm{ft}$.

16. unidentified left maxilla, GIT641-16, sample $484.7 \mathrm{ft}$.

17. labidognath basal plate, GIT641-17, sample $497.8 \mathrm{ft}$.

18. labidognath basal plate, GIT641-18, sample $497.8 \mathrm{ft}$.

19. labidognath? basal plate, GIT641-19, sample $497.8 \mathrm{ft}$.

20. labidognath basal plate, GIT641-20, sample $484.7 \mathrm{ft}$.

21. labidognath? basal plate, GIT641-21, sample $497.8 \mathrm{ft}$. 
22. polychaetaspid? carrier, GIT641-22, sample $452.75 \mathrm{ft}$.

23. Oenonites? sp., carrier, GIT641-23, sample $452.75 \mathrm{ft}$.

24. labidognath basal plate, GIT641-24, sample $484.7 \mathrm{ft}$.

25. labidognath basal plate, GIT641-25, sample $484.7 \mathrm{ft}$.

26. Oenonites? sp., basal plate, GIT641-26, sample $484.7 \mathrm{ft}$.

27. labidognath? basal plate, GIT641-27, sample $484.7 \mathrm{ft}$.

Plate II. Ramphoprionids and other selected scolecodonts from the Upper Ordovician of the Qusaiba-1 core hole. All specimens from the Quwarah Member of the Qasim Formation, latest Katian or earliest Hirnantian. Same scale is used throughout; specimens are in dorsal view unless noted otherwise.

1-12. Gen et sp. indet. 1;

1. left MI, GIT641-28, sample $497.8 \mathrm{ft}$.

2. right MI, GIT641-29, sample $497.8 \mathrm{ft}$.

3. right MI, GIT641-30, sample $497.8 \mathrm{ft}$.

4. right MI, GIT641-31, sample $497.8 \mathrm{ft}$.

5. right MI, GIT641-32, sample $484.7 \mathrm{ft}$.

6. left MI in half-lateral view, GIT641-33, sample $497.8 \mathrm{ft}$.

7. left MI, GIT641-34, sample $497.8 \mathrm{ft}$.

8. $\quad$ right $\mathrm{MI}$, GIT641-35, sample $484.7 \mathrm{ft}$.

9. left MI, GIT641-36, sample $484.7 \mathrm{ft}$.

10. right MI in outer lateral view, GIT641-37, sample $497.8 \mathrm{ft}$.

11. right $\mathrm{MI}$ in outer lateral view, GIT641-38, sample $497.8 \mathrm{ft}$. 
12. left MI, GIT641-39, sample $497.8 \mathrm{ft}$.

13. ramphoprionid? right MI, GIT641-40, sample $484.7 \mathrm{ft}$.

14. ramphoprionid? right MI, GIT641-41, sample $484.7 \mathrm{ft}$.

15-27. anterior maxillae most likely belonging to Gen et sp. indet. 1.

15. right MII in outer lateral view, GIT641-42, sample $497.8 \mathrm{ft}$.

16. right MIV?, GIT641-43, sample $484.7 \mathrm{ft}$.

17. broken right MII, GIT641-44, sample $497.8 \mathrm{ft}$.

18. right MII, GIT641-45, sample $484.7 \mathrm{ft}$.

19. right MII, GIT641-46, sample $497.8 \mathrm{ft}$.

20. right MII, GIT641-47, sample $484.7 \mathrm{ft}$.

21. left MIII?, GIT641-48, sample $497.8 \mathrm{ft}$.

22. left MIV?, GIT641-49, sample $452.75 \mathrm{ft}$.

23. left MII, carrier, GIT641-50, sample $497.8 \mathrm{ft}$.

24. right MII, GIT641-51, sample $497.8 \mathrm{ft}$.

25. left MII, GIT641-52, sample $497.8 \mathrm{ft}$.

26. left MII, GIT641-53, sample $497.8 \mathrm{ft}$.

27. left MII, GIT641-54, sample $484.7 \mathrm{ft}$.

Plate III. Paulinitids, atraktoprionids and other selected scolecodonts from the Upper

Ordovician of the Qusaiba-1 core hole. All specimen from the Quwarah Member of the Qasim Formation, latest Katian or earliest Hirnantian, except H, I, and Y, which come from the basal Sarah Formation ("disrupted facies"), Hirnantian. Same scale is used throughout; specimens are in dorsal view unless noted otherwise. 
1-11. Kettnerites sp.

1. $\quad$ left MI, GIT641-55, sample $497.8 \mathrm{ft}$.

2. left MI, GIT641-56, sample $497.8 \mathrm{ft}$.

3. left MI, GIT641-57, sample $497.8 \mathrm{ft}$.

4. left MI, GIT641-58, sample $484.7 \mathrm{ft}$.

5. right MI, GIT641-59, sample $484.7 \mathrm{ft}$.

6. right, GIT641-60, sample $497.8 \mathrm{ft}$.

7. right MI, GIT641-61, sample $497.8 \mathrm{ft}$.

8. left MII in half-lateral view, GIT641-62, sample $528.3 \mathrm{ft}$.

9. left MII in half-lateral view, GIT641-63, sample $528.3 \mathrm{ft}$.

10. left MII, GIT641-64, sample $484.7 \mathrm{ft}$.

11. left MII in half-lateral view, GIT641-65, sample $497.8 \mathrm{ft}$.

12. Atraktorpion sp. 1, right MI, GIT641-66, sample $484.7 \mathrm{ft}$.

13. Atraktorpion sp., right MI, GIT641-67, sample $497.8 \mathrm{ft}$.

14. Atraktorpion sp. 2, left MI, GIT641-68, sample $497.8 \mathrm{ft}$.

15. Atraktorpion sp. 2, left MI, GIT641-69, sample $497.8 \mathrm{ft}$.

16. Atraktorpion sp. 3, left MI, GIT641-70, sample $497.8 \mathrm{ft}$.

17. Atraktorpion sp. 2, left MI, GIT641-71, sample $497.8 \mathrm{ft}$.

18. Atraktorpion sp. 1, left MI, GIT641-72, sample $497.8 \mathrm{ft}$.

19. Atraktorpion sp. 1, right MI, GIT641-73, sample $497.8 \mathrm{ft}$.

20. Atraktorpion sp. 2, right MI, GIT641-74, sample $497.8 \mathrm{ft}$.

21. prionognath right anterior maxilla, GIT641-75, sample $497.8 \mathrm{ft}$.

22. prionognath right anterior maxilla, GIT641-76, sample $497.8 \mathrm{ft}$.

23. Kalloprion? sp., right MI, carrier, GIT641-77, sample $497.8 \mathrm{ft}$. 
24. prionognath right anterior maxilla, GIT641-78, sample $497.8 \mathrm{ft}$.

25. Gen. et sp. indet. 1?, carrier, GIT641-79, sample $452.75 \mathrm{ft}$.

26. Kettnerites sp.?, carrier, GIT641-80, sample $497.8 \mathrm{ft}$.

27. Kettnerites sp.?, carrier, GIT641-81, sample $497.8 \mathrm{ft}$.

28. prionognath right anterior maxilla, GIT641-82, sample $497.8 \mathrm{ft}$.

29. placognath left MI, GIT641-83, sample $497.8 \mathrm{ft}$.

30. unknown placognath? jaw, specimen on permanent chitinozoan slide (Rennes University), sample $497.8 \mathrm{ft}$. 
Fig 1

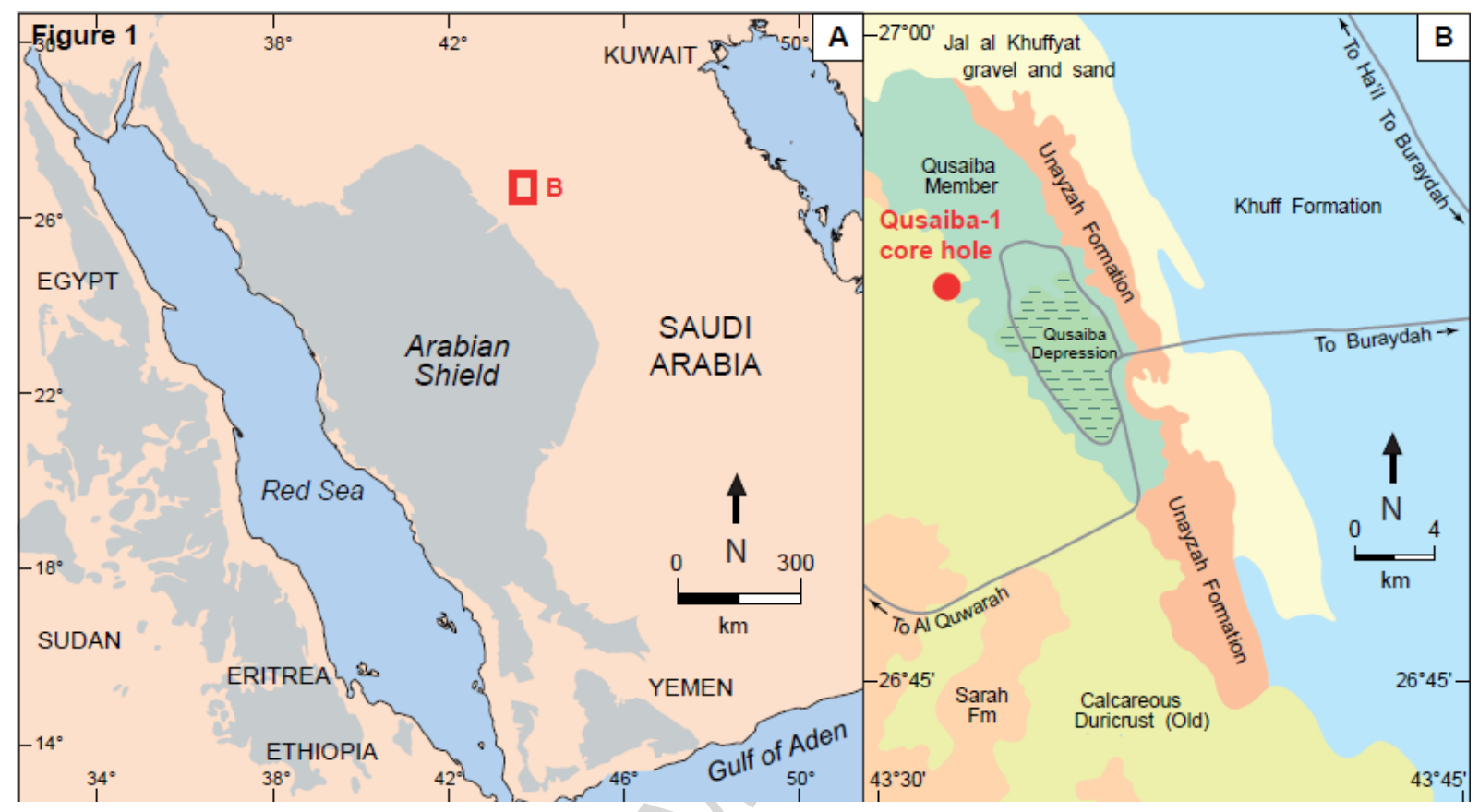


Fig 2

Figure ${ }^{2}$ hrono-, bio-, and lithostratigraphy

Distribution of scolecodonts

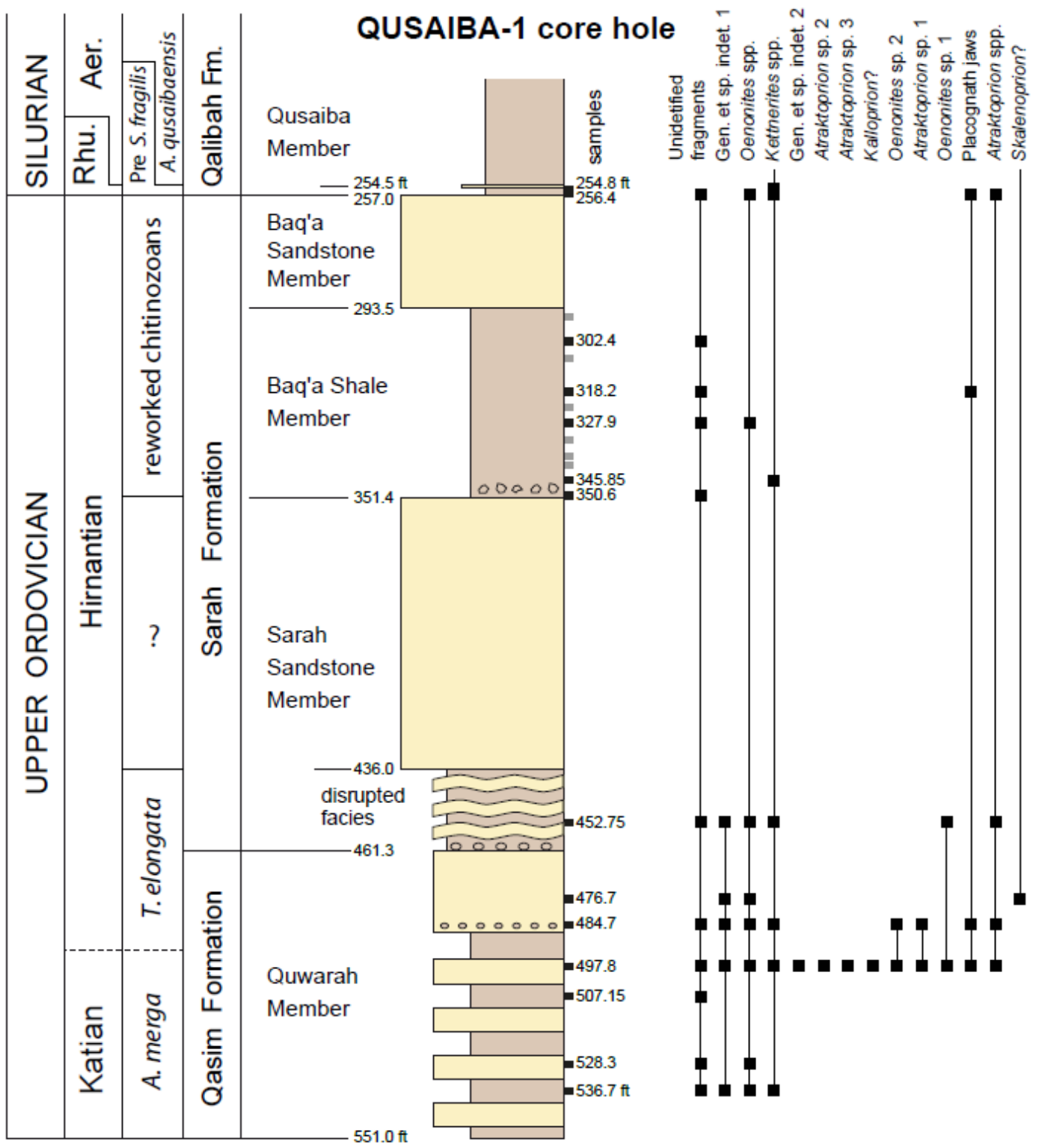


Fig 3

Figure 3
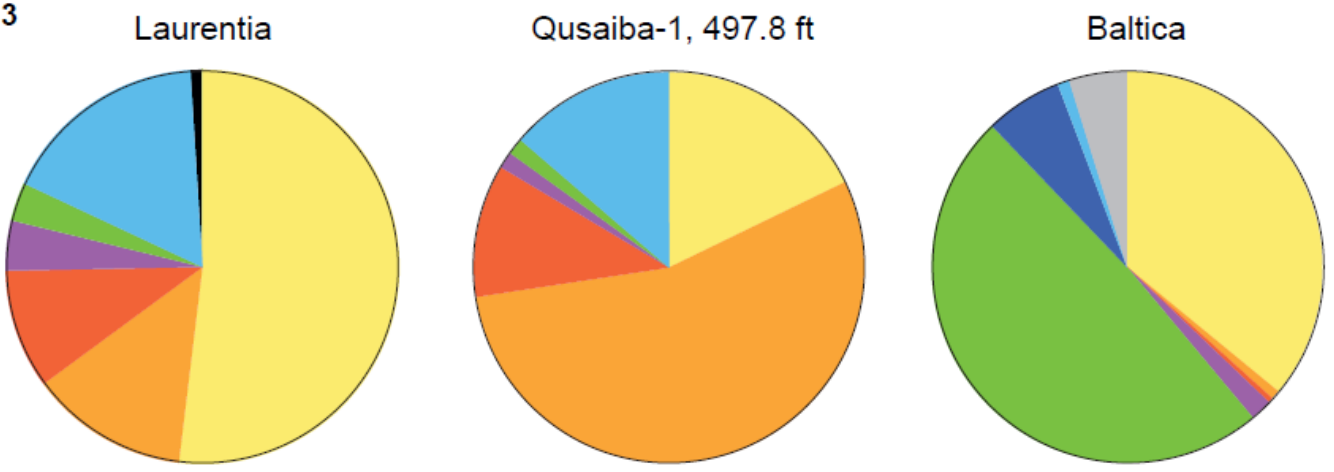

Polychaetaspida

$\square$ Ramphoprionidae

Atraktoprionidae

Kalloprionidae

Polychaeturidae

$\square$ Paulinitidae

- Hadoprionidae

$\square$ Other 
Plate 1

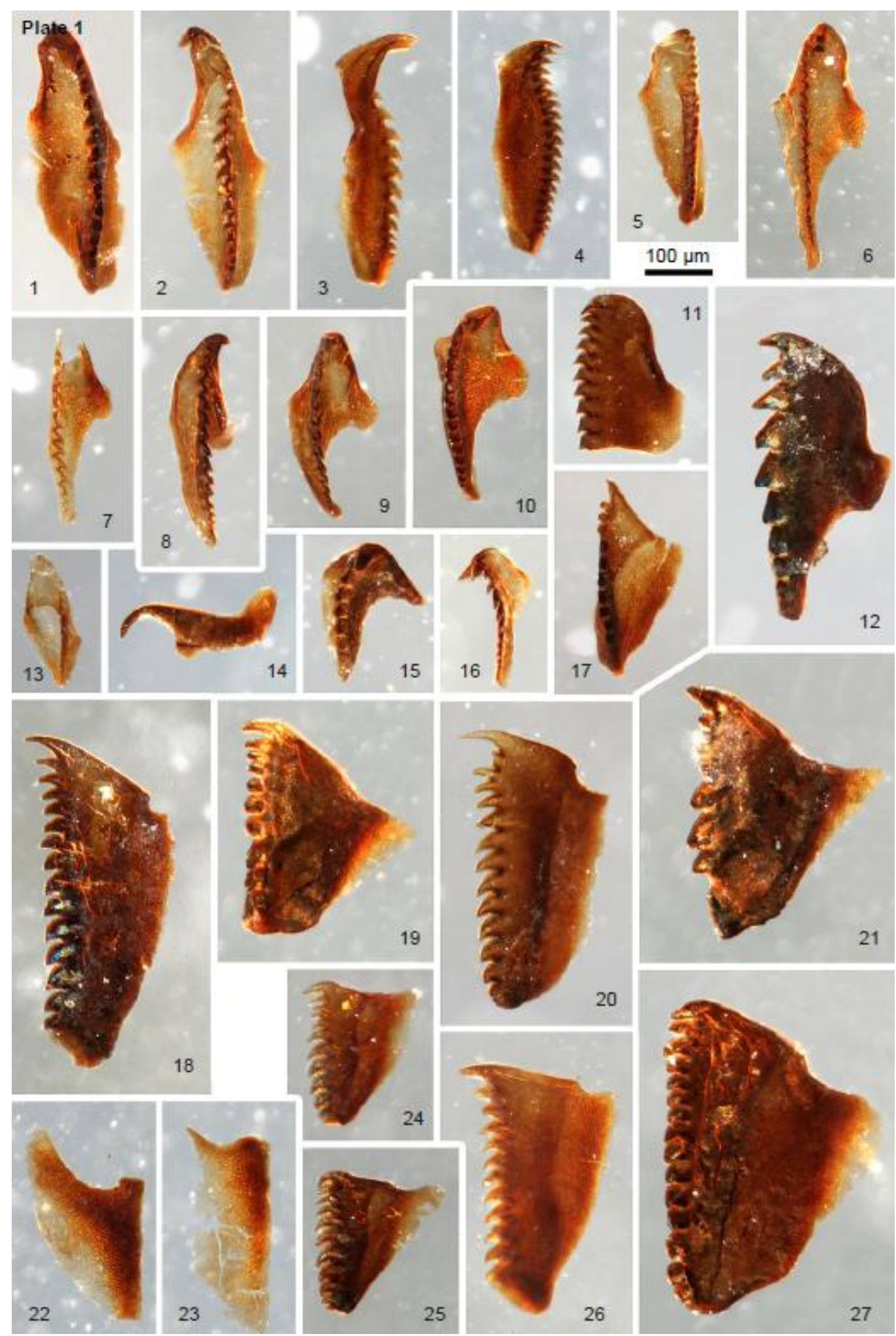


Plate 2

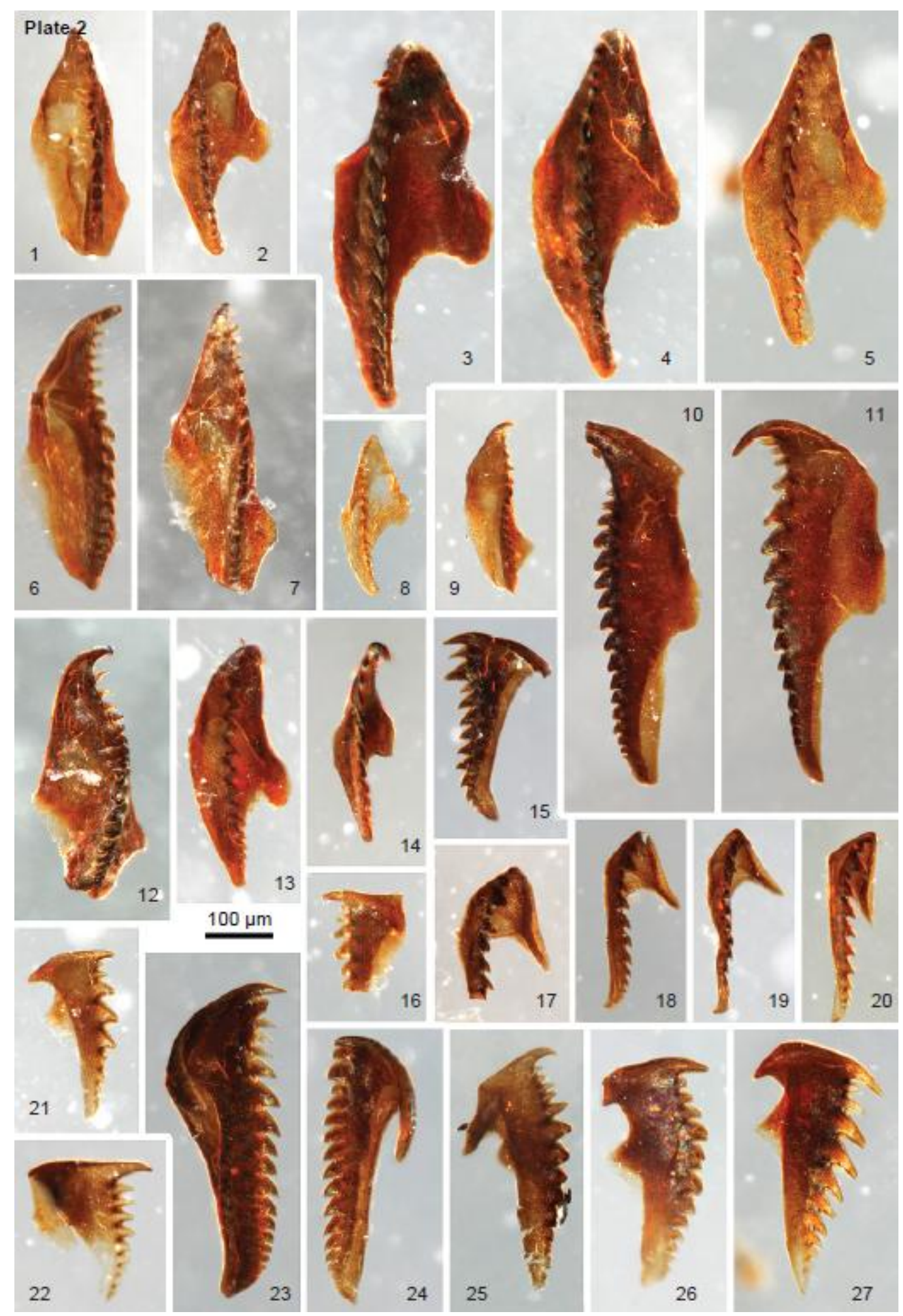


Plate 3

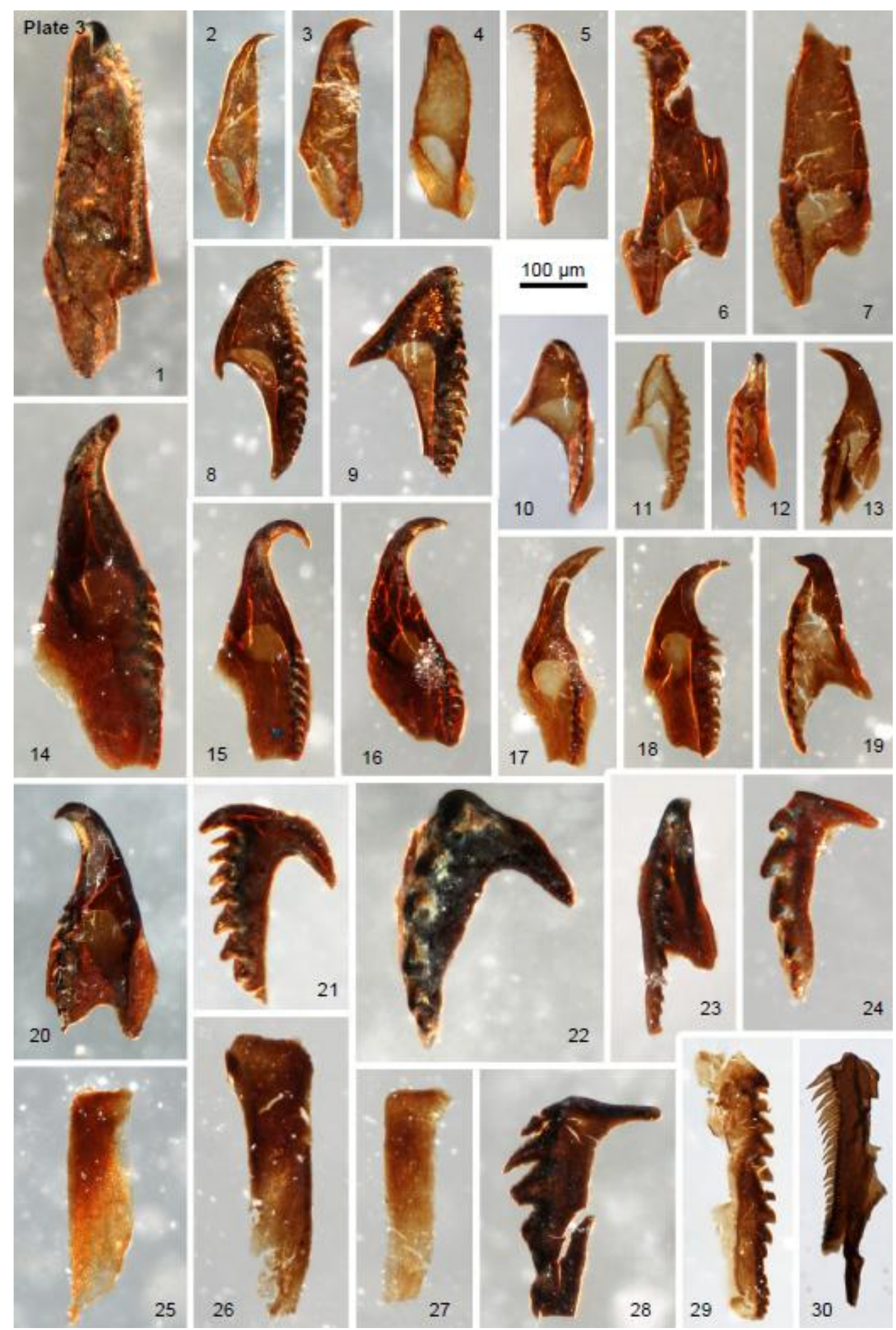

